\title{
Peran Dan Partisipasi Masyarakat Dalam Pelestarian Dan Pengembangan Budaya
}

\section{Sambung Widodo}

Keywords: cultural resource management, conservation, utilization, heritage, community, participatory

\section{How to Cite:}

Widodo, S. (2004). Peran Dan Partisipasi Masyarakat Dalam Pelestarian Dan Pengembangan Budaya. Berkala Arkeologi, 24(1), 65-71. https://doi.org/10.30883/jba.v24i1.895

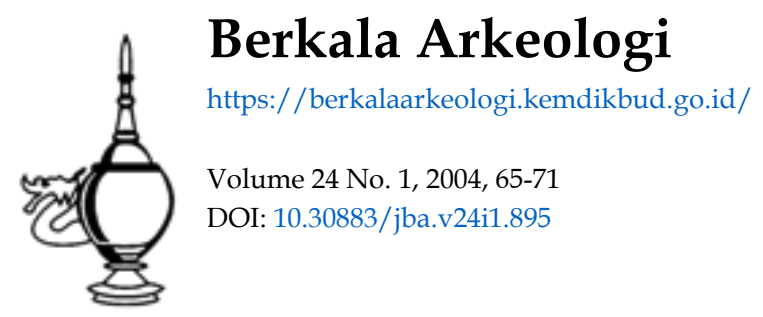

\section{(c) (1) (2) (2)}

This work is licensed under a Creative Commons Attribution-NonCommercial-ShareAlike 4.0 International License. 


\section{PERAN DAN PARTISIPASI MASYARAKAT DALAM PELESTARIAN DAN PENGEMBANGAN BUDAYA}

\section{Sambung Widodo}

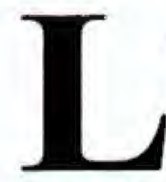

atar Belakang Perlunya Pembangunan Pariwisata Berbasis Komunitas

Akhir-akhir ini paradigma pembangunan pariwisata yang berbasis masyarakat menjadi sangat populer dalam perencanaan dan pengembangan pariwisata. Paradigma tersebut muncul di dorong oleh kesadaran bahwa pembangunan tidak akan berhasil dan berkelanjutan tanpa ada keterlibatan peran masyarakat. Dalam banyak diskusi para pakar dan praktisi pariwisata, wacana tersebut selalu menjadi topik yang menarik untuk dibicarakan. Namun pemahaman paradigma pembangunan yang berbasis pada masyarakat selama ini masih diartikan terlalu sempit, karena hanya dipandang dari perspektif ekonomi. Apabila hal ini di biarkan berkembang, maka nasib paradigma tersebut hanya berhenti pada wacana saja, dan akibatnya tidak akan jauh berbeda dengan nasib sejarah perkembangan pariwisata.

Selama ini pengembangan pariwisata hanya di pandang sebelah mata dari keuntungan ekonomi. Yang dikejar hanya profit bagi pemerintah(Negara), bukan benefit bagi masyarakat lokal, sehingga perspektif lain dari pariwisata tidak begitu dihiraukan. Aspek social, budaya, politik dan pelestarian lingkungan terabaikan. Hal ini tampak pada indikator yang digunakan sebagai tolok ukur keberhasilan pengembangan pariwisata selama ini. Indikator yang digunakan hanya dari aspek ekonomi antara lain devisa, dan PAD. Indikator-indikator tersebut sangat tergantung dari jumlah kedatangan wisatawan, Length of Stay, dan Total Expenditure.

Dampak dari konsep pembangunan pariwisata yang hanya mengejar pertumbuhan ekonomi tersebut beriplikasi pada terabaikannya berbagai aspek yang terkait dengan kepariwisataan. Sumberdaya alam dan budaya dieksploitasi sedemikian rupa sehingga mengabaikan kelestariannya. Peran masyarakat termaginalkan dan hanya dipandang sebagai obyek pembangunan. Dalam wacana pembangunan klasik yang sangat sentralistik dan berorientasi pada pertumbuhan ekonomi, peran dan partisipasi masyarakat dalam pembangunan kepariwisataan dipahami semata-mata dari perspektif negara sebagai pemilik resources dan pemilik otoritas pembangunan. Dalam kondisi seperti ini peran masyarakat ditentukan seberapa besar masyarakat telah melaksanakan apa yng menjadi program pemerintah. Hal ini wajar karena dalam ideologi developmentalism yang menjadi landasan operasional pembangunan kepariwisataan selama ini, peran masyarakat didefinisikan dan dilekatkan dengan wacana kekuasaan (power). Dari perspektif ini peran dan partisipasi diartikan sebagai pelaksanaan kewajiban yang telah ditetapkan pemerintah (negara) meskipun hal itu seringkali tidak sesuai atau bahkan bertentangan dengan kehendak masyarakat (Hendrie Adji K, 2000). Kegiatan pembangunan pariwisata yang berdasarkan 
pendekatan tersebut di atas berdampak pada kerusakan lingkungan, masalah sosial, dan kesenjangan masyarakat.

Dalam menghadapi permasalahan tersebut, muncul wacana untuk melakukan perubahan orientasi pembangunan pariwisata yang berbasis pada masyarakat untuk mengoreksi kesalahan paradikma pembangunan yang sentralistik, dengan mengintroduksi prinsip pembangunan berkelanjutan. Paradikma ini selain dipicu oleh permasalahan sosial, juga untuk mengantisipasi isu internasional tentang kelestarian lingkungan hidup.

Perbedaan prinsip paradigma pembangunan dengan model pertumbuhan dengan paradigma model keberlanjutan dapat diuraikan dalam bagan berikut:

Pergeseran Paradigma Pembangunan Pariwisata

\begin{tabular}{|c|c|c|c|}
\hline $\begin{array}{l}\text { Parameter/Indika } \\
\text { tor }\end{array}$ & Model Pertumbuhan & Model Keberlanjutan & Keterangan \\
\hline $\begin{array}{l}\text { A. Nilai yang } \\
\text { dikejar }\end{array}$ & Growth $\rightarrow$ Devisa & $\begin{array}{l}\text { Development(Communi } \\
\text { ty based Tourism } \\
\text { Development) }\end{array}$ & $\begin{array}{l}\text { Distribusi } \\
\text { kesejahteraan } \\
\text { masyarakat setempat } \\
\text { Kelestarian } \\
\text { (Sustainability) }\end{array}$ \\
\hline $\begin{array}{r}\text { B.Masyarakat } \\
\text { - Akses } \\
\text { - Peran } \\
\text { - Karakter } \\
\text { - Posisi }\end{array}$ & $\begin{array}{c}\text { Terbatas-Tertutup } \\
\text { Pasif } \\
\text { Penerima subsidi } \\
\text { Beneficiaries } \\
\text { Marjinal }\end{array}$ & $\begin{array}{c}\text { Terbuka thd. Peluang } \\
\text { Aktif-partisipatif } \\
\text { Enterpreneur } \\
\text { Stakeholder }\end{array}$ & \\
\hline $\begin{array}{l}\text { C.Peran } \\
\text { Pemerintah }\end{array}$ & $\begin{array}{c}\text { Initikator s/d } \\
\text { Developer }\end{array}$ & Fasilitator & $\begin{array}{l}\text { Pemerataan } \\
\text { Stakeholder }\end{array}$ \\
\hline $\begin{array}{l}\text { D. Ukuran } \\
\text { Sukses }\end{array}$ & $\begin{array}{l}\text { - Jumlah } \\
\text { kunjungan } \\
\text { - Lama } \\
\text { Tinggal } \\
\text { - Tingkat } \\
\text { pembelanjaan }\end{array}$ & $\begin{array}{l}\text { Besarnya nilai } \\
\text { multiganda }\end{array}$ & $\begin{array}{l}\text { Nilai } \\
\text { serapan/penaikan: } \\
\text { - Income } \\
\text { masyarakat } \\
\text { - Tenaga kerja } \\
\text { ekspor Komponen } \\
\text { Pajak pemerintah }\end{array}$ \\
\hline $\begin{array}{l}\text { E.Tuntutan } \\
\text { Standar Kualitas }\end{array}$ & Local & Universal & $\begin{array}{l}\text { - Ecolabeling } \\
\text { - Ramah } \\
\text { Gender } \\
\text { - Animal } \\
\text { Right } \\
\text { - HAM } \\
\text { - Environment } \\
\text { ally Friendly }\end{array}$ \\
\hline
\end{tabular}




\begin{tabular}{|c|c|c|c|}
\hline $\begin{array}{l}\text { F.Pola } \\
\text { Manajemen }\end{array}$ & $\begin{array}{c}\text { Monopoli- } \\
\text { Monopsoni-Oligopoli }\end{array}$ & $\begin{array}{ll}\text { - } & \text { Transparansi } \\
\text { - } & \text { Akuntabilitas } \\
\text { - } & \text { Profesional } \\
\text { - } & \text { Pola } \\
\text { Kemitraan }\end{array}$ & Good Governance \\
\hline
\end{tabular}

Perbedaan paradigma tersebut secara rinci dapat diuraikan sebagai berikut:

a. Pada model pertumbuhan nilai yang dikejar adalah kenaikan devisa dari segala sektor, sedangkan pada model keberlanjutan adalah pemberdayaan masyarakat. Community Based Tourism Development menekankan pentingnya melibatkan seluruh potensi yang ada dalam masyarakat lokal dalam pembangunan pariwisata. Nilai-nilai yang dikejar adalah distribusi kesejahteraan bagi masyarakat yang meliputi benefit for local people, quality of life, income generating, environmentally friendly.(WTO,1993).

b. Pada model pertumbuhan, akses masyarakat terhadap pelaksanaan suatu program pemerintah sangat terbatas bahkan berkesan tertutup, sedangkan pada model keberlanjutan cukup terbuka peluang bagi masyarakat untuk terlibat di dalamnya. Peran masyarakat dahulu sangat pasif hanya sebagai obyek dari pembangunan yang dilaksanakan oleh pemerintah. Sedangkan pada model keberlanjutan peran masyarakat diharapkan aktif sejak dalam proses perencanaan, implementasi, dan pengelolaan serta monitoring, karena yang akan memanfaatkan hasil dari program-program tersebut nantinya adalah masyarakat itu sendiri. Masyarakat didorong untuk aktif berpartisipasi sebagai subyek, tidak hanya menerima hasil dari suatu pelaksanaan suatu program pembangunan tetapi ikut merencanakan, meleksanakan, dan memanfaatkan hasil-hasil pembangunan tersebut secara maksimal. Pada model pertumbuhan, posisi masyarakat termarjinalkan karena mereka berdiri diluar sistem kebijakan. Sedangkan sekarang masyarakat merupakan salah satu komponen penentu kebijakan dan aktif melakukan kontrol terhadap kegiatan yang mempengaruhi kehidupannya.(Kreg Lindberg\& Donald Hawkins, 1995).

c. Peran pemerintah pada model pertumbuhan adalah sebagai inisiator atau pencetus ide atau gagasan, negosiator sampai pelaksana ide atau gagasan tersebut. Tetapi pada model keberlanjutan, peran pemerintah sebagai fasilitator dari pelaksanaan suatu gagasan/program dan lebih berperan untuk melakukan fungsi-fungsi koordinasi , mediasi dan arbitrasi. Pelaksanaan suatu program atau kebijakan lebih merata pada tiga komponen stakeholder, yaitu: pemerintah, masyarakat, dan swasta.(Kreg Lindberg \& Donald E Hawkins, 1995).

d. Ukuran sukses pada model pertumbuhan adalah naiknya Number of Tourist, Length of Stay dan Expenditure of Tourist tanpa memperhitungkan dampak mulitganda (multiplier effect) dari suatu kegiatan wisata. Suatu kegiatan wisata bila dilihat secara menyeluruh akan berdampak pada naiknya pendapatan masyarakat khususnya mereka yang terkait dengan kegiatan tersebut (baik langsung maupun tidak langsung). Terbukanya kesempatan kerja yang berdampak 
pada penyerapan tenaga kerja yang sangat besar pada sektor ini. Kenaikan komponen ekspor beberapa produk (misal cenderamata) dengan adanya kegiatan ini. Selain itu juga menaikkan nilai Pajak Pemerintah dari berbagai aspek yang terkait dengan kegiatan kepariwisataan.(WTO,1995).

e. Pada model pertumbuhan tuntutan standar kualitas hanya disesuaikan dengan standar lokal-regional setempat, sedangkan model pertumbuhan juga memperhatikan standar kualitas internasional yang ada seperti Ecolabeling, Ramah Gender, Animal Right, HAM dan Environmentally Friendly.

f. Pada model pertumbuhan, pola menejemen yang diterapkan adalah di satu tangan (baik oleh pemerintah maupun pihak-pihak tertentu yang mempunyai otoritas) seperti pola-pola monopoli, monopsoni, maupun oligopoly. Sedangkan pada model keberlanjutan, pemerintah diharapkan untuk menerapkan sistem penyelenggaraan pemerintah yang transparan, akuntabel, professional dan menerapkan pola kemitraaan dengan swasta dan masyarakat.

\section{I} mplementasi Pembangunan Pariwisata Berbasis Komunitas

Dalam implementasi, pengertian pembangunan pariwisata berkelanjutan semestinya dipahami dalam keseluruhan dimensinya baik secara vertikal maupun horisontal, yaitu inter-generation dan inter-region. Bagaimanapun keberlanjutan inter generation tidak akan tercapai tanpa keberlanjutan inter region (Hendrie Adji K,2000). Berkaitan dengan itu seharusnya pembangunan pariwisata memperhitungkan peran dan partisipasi masyarakat.

Perubahan di era reformasi saat ini juga mendorong munculnya tuntutan demokratisasi sehingga menuntut perubahan paradigma pembangunan yang menekankan pemberian peran yang cukup strategis bagi masyarakat lokal.

Secara strategis peran didefinisikan sebagai fungsi yang dinamis dari status. Status merupakan seperangkat hak dan kewajiban yang di tentukan oleh proses sosial dalam masyarakat. Dalam hal ini partisipasi sebagai media untuk mengaktualisasikan peran juga memiliki dimensi hak dan kewajiban, oleh karenanya mempertanyakan seberapa besar peran dan partisipasi masyarakat dalam pembangunan pariwisata seharusnya tidak hanya mempertanyakan seberapa besar mereka memenuhi kewajiban tetapi juga seberapa besar hak yang didapatkan .(Hendrie Adji K,2000).

Masyarakat merupakan bagian yang berpotensi menyediakan cultural environment experience, sehingga pertisipasi masyarakat dalam perencanaan harus terintegrasi dalam setiap tahap proses perencanaan yang meliputi : problem identification, planning process, projection, assessment, evaluation, mitigation, monitoring. 
Beberapa prinsip berikut merupakan satu kesatuan factor yang tidak dapat dipisahkan dalam proses pelembagaan pembagunan pariwisata berbasis komunitas. (Laretna $T$ Adhisakti, 2003).

a. Masyarakat sebagai pusat pengelola (people centered management).

b. Kerja sama dan kolaborasi interdisipliner dan lintas sektoral.

c. Terciptanya mekanisme kelembagaan yang mampu mengakomodasi apresiasi dan aksi masyarakat.

d. Dukungan dan penegakan aspek legal.

e. Perlu diwujudkan pasar pelestarian sumber daya alam dan budaya yang menunjang kesinambungan pengelolaan.

Peningkatan peran dan partisipasi masyarakat perlu ditumbuhkan melalui usaha yang terus menerus tiada henti dalam jangka panjang. Usaha tersebut meliputi beberapa tahap yaitu: tepung, dunung, srawung. Pada tahap awal masyarakat perlu mengenali (tepung) apa yang menjadi potensi sumber daya alam dan budaya yang dimilikinya. Tahap selanjutnya masyarakat perlu mengetahui (dunung) bagaimana mengembangkan dan memanfaatkan potensi yang dimilikinya. Pada ahirnya masyarakat memahami (srawung) dan menghargai bahwa potensi sumber daya alam dan budaya yang mampu dipelihara dan dikembangkan dapat memberikan manfaat bagi kehidupannya, meningkatan kesejahteraan secara material dan spiritual.

\section{Peran dan Partisipasi Masyarakat Dalam Pelaksanaan dan Pengelolaan Pembangunan Pariwisata}

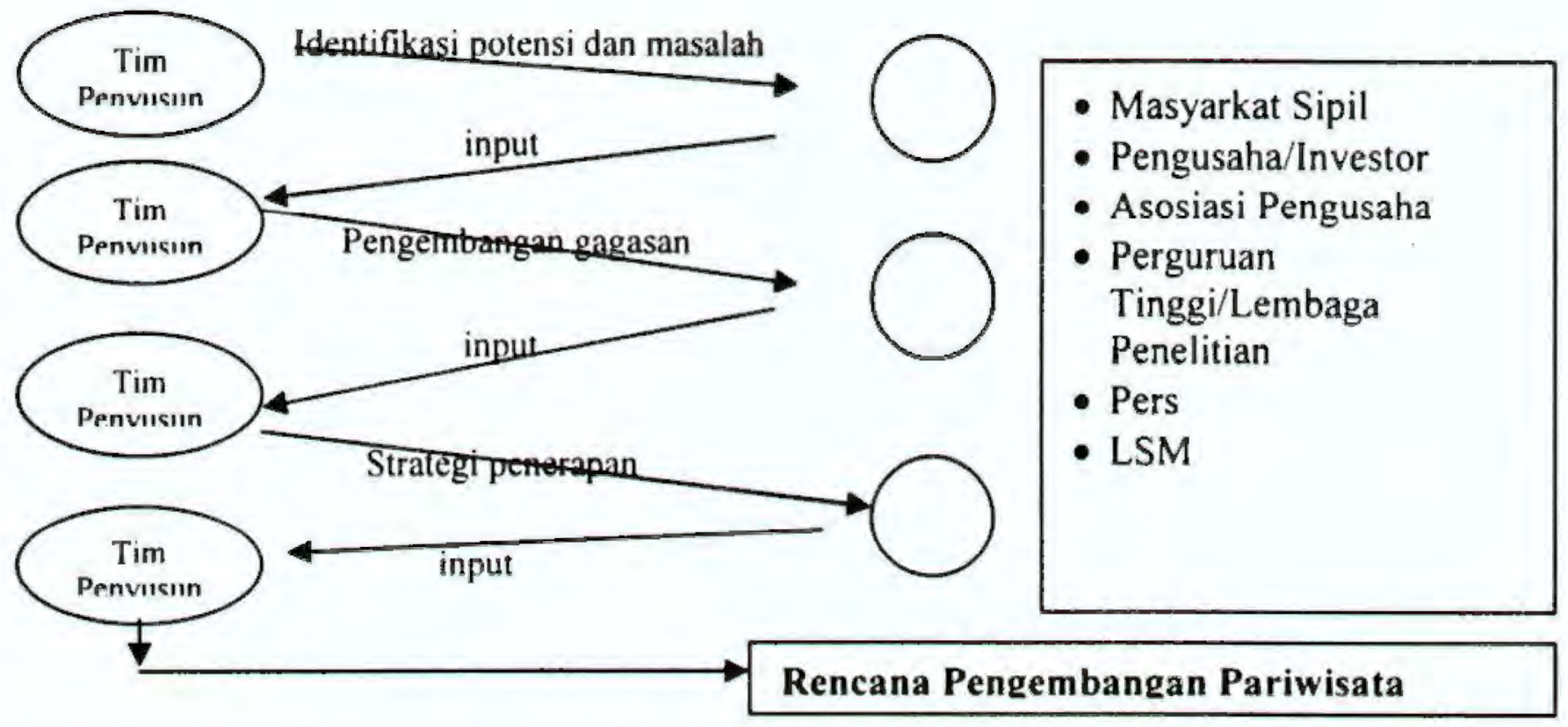




\section{Peran dan Partisipasi Masyarakat Dalam Penyusunan Rencana Pembangunan Pariwisata}

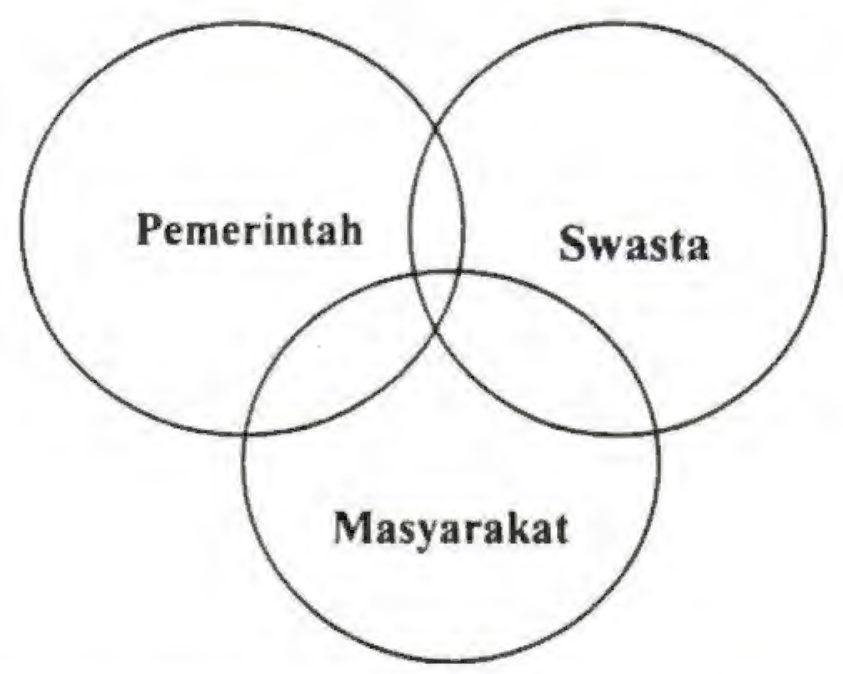

Konfigurasi tersebut menggambarkan keserasian dan keseimbangan kedudukan antar stakeholder pengembangan pariwisata yang meliputi:

- Kewenangan dan otoritas dalam perencanaan implementasi dan pengelolaan

- Peran dan partisipasi dalam perencanaan implementasi dan pengelolaan

- Hak dan Kewajiban dalam manajemen pengelolaan dan monitoring

\section{KEPUSTAKAAN}

Adishakti, Laretna T., 2003, Community Participation and Future Development of Borobudur Temple and its Environtment, Paper presented in the Fourth International Experts Meeting on Borobudur, organized by Ministry of Culture and Tourism in collaboration with UNESCO in Borobudur, Magelang, 4-8 July 2003.

Pelestarian Pusaka Budaya: Masyarakat Sebagai Pusat Pengelolaan Perubahan, Makalah disampaikan dalam Pra Kongres Kebudayaan pada tanggal 28-30 April 2003 di Denpasar, Bali.

Anonim, 1998, Guide for Local Authorities on Developing Sustainable Tourism, A Tourism and Environment Publication, World Tourism Organization. 
Kusworo, Hendrie Adji, 2000, Pengembangan Wisata Pedesaan Tepi Hutan Berbasis Kerakyatan, Pengusahaan Ekowisata, Yogyakarta: Fakultas Kehutanan UGM.

Kusworo, Hendrie Adji, 2002, Perencanaan Pariwisata, Makalah dalam Kegiatan Peningkatan Kemampuan Teknis Operasional Aparat Dinas Kebudayaan dan Pariwisata Propinsi dan Kabupaten/Kota Yogyakarta di Hotel Phoenix Yogyakarta.

Enhancing The Rule of Community in Tourism Destination: Community and Institutional Development Perspectives (Indonesia Case Studies), Makalah yang disampaikan pada: 2003 Asian Uninet Workshop Location and Attractiveness Studies in Tourism: Supporting Tools for Tourism Policies, Bangkok Thailand 1-3 Desember 2003.

Lindberg, Kreg \& Hawkins, Donald E, 1995, Ecotourism: A Guide for Planners and Managers, The Ecotourism Society, North Bennington, Vermont.

Nasikun, Globalisasi dan Paradigma Baru Pembangunan Pariwisata Berbasis Komunitas, Pengusahaan Ekowisata, Yogyakarta: Fakultas Kehutanan UGM. 